\title{
The Role of Statistical Analysis in Ensuring the Competitiveness of Tourism (Case of Uzbekistan)
}

\author{
Mirzayev Kulmamat Djanzakovich, Janzakov Bekzot Kulmamat ugli
}

\begin{abstract}
This article discusses the importance of statistical data in planning the activities of tourism organizations. Also, the general trends in inbound and domestic tourism are identified and evaluated. The seasonality of inbound tourism turned out to be highly dependent on weather temperature. The importance of hotel classification and its influence on marketing power of tour packages is discussed.
\end{abstract}

Keywords: inbound tourism, domestic tourism, hotel classification, statistics, seasonality

\section{INTRODUCTION}

Tourism is becoming an important part of the economy in Uzbekistan. Therefore, studying the impact of tourism on the economy will help to understand how to develop the sector. In particular, the completeness and accuracy of statistics is very important for tourism development.

Tourism information can be quantitative and qualitative. According to Chris Holloway and others, following tourism information is collected in the UK [4]:

- monthly number of international and domestic tourists;

- the countries' generating the international tourists and the regions' generating the domestic tourists;

- their expenditures: in absolute terms and how they distribute it between accommodation, transport, shopping, catering and so on;

- their mode of travel - that is, what form of transport they use, whether they are travelling independently or on an inclusive tour;

- duration of the visit;

- types of accommodation used by tourists;

- purpose of travel: vacation, work, visit of relatives, etc.;

- information on the age of tourists, social status;

- demographic profiles - age, group composition, social class;

- socio-graphic profiles - personality, lifestyle, interests and activities;

Revised Manuscript Received on December 30, 2019.

* Correspondence Author

Prof. Mirzaev Kulmamat Djanzakovich, Vice-Rector of Samarkand Institute of Economics and Service, Samarkand, Uzbekistan. info@sies.uz, (+998) 662213233

Janzakov Bekzot Kulmamat ugli, Ph.D. scholar, Samarkand State University, Samarkand, Uzbekistan, becajaja@gmail.com,_(+998) 91554 9087

(C) The Authors. Published by Blue Eyes Intelligence Engineering and Sciences Publication (BEIESP). This is an open access article under the CC BY-NC-ND license (http://creativecommons.org/licenses/by-nc-nd/4.0/)
- interests of the tourists and the extent to which they are satisfied with what they find.

According to David Bartle, statistics is the main tool in an objective assessment of tourism policy [1]. Obviously, tourism statistics is crucial in both describing and quantifying the outcomes, particularly length of stay, visitor type, expenditure and satisfaction. The statistical data itself is useless without being applied in evaluation. Evaluation ranges from national tourism authority key performance indicator reporting, to work used to inform national tourism agency [12]. According to Trochim [11:248] "evaluation is a profession that uses formal methodologies to find useful empirical evidence about public entities (such as programs, products, performance) in decision making contexts which are inherently political and involve multiple, often conflicting stakeholders, where resources are seldom sufficient and where time pressures are salient". While statistical information is the material on which evaluation is constructed, the process of evaluation itself is the reflection of complex processes of real life. The main purpose of our research is evaluating the contemporary state of tourism in the Republic of Uzbekistan. We analyzed the official statistical data presented by the State Committee of the development of Tourism for the year of 2018. The analysis comprises general trends in inbound and domestic tourism, as well as the classification of hotels in Uzbekistan. Based on the results of analysis appropriate recommendations are worked out for further development of tourism in regions.

\section{THE ANALYSIS OF INBOUND TOURISM}

The object of analysis - we tried to evaluate various factors determining the development and competitiveness of tourism sphere using official statistical data. In particular, we reviewed the number of tourists that used local tour companies, dynamics of the number of inbound tourists to Uzbekistan and the impact of weather temperature on the international tourist arrivals.

The method of analysis - the analysis is based on official statistical data presented by the State Committee of the development of tourism of Uzbekistan. We used graphical interpretation and linear regression analysis to carry out evaluations. The number of foreign tourists visiting Uzbekistan in 2018 amounted to 5.346 millions, of which $93.8 \%$ were from the former Soviet countries ${ }^{1}$. According to

${ }^{1}$ Data of the State Committee for Tourism Development and the State Committee for Statistics of the Republic of Uzbekistar

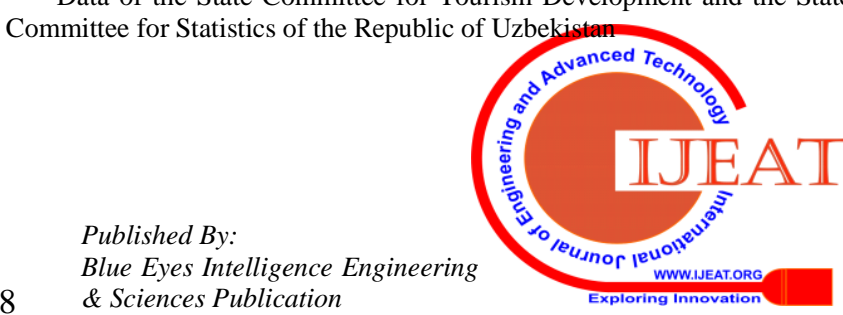


the survey carried out in June 2018, the majority of foreign tourists (43.6\%) stayed at the accommodation of their family and friends. And $85.1 \%$ of these people were from Central Asia. Most tourists from Europe (34\%) preferred to stay in the hotels ranged from 2 to 5 stars. The same proportion is true for other tourists from the Middle East, Americas and Africa $^{2}$. The majority of respondents (79\%) came to stay for about 1 to 9 nights. If we look at the diagram below (fig. 1), we can notice the steady rise of the inbound tourism between 2000 and 2017. However, in 2018 the amount doubled relative to previous year skyrocketing from 2.6 million up to 5.4 million people.

The dynamics of inbound tourism of Uzbekistan. Diagramm №1

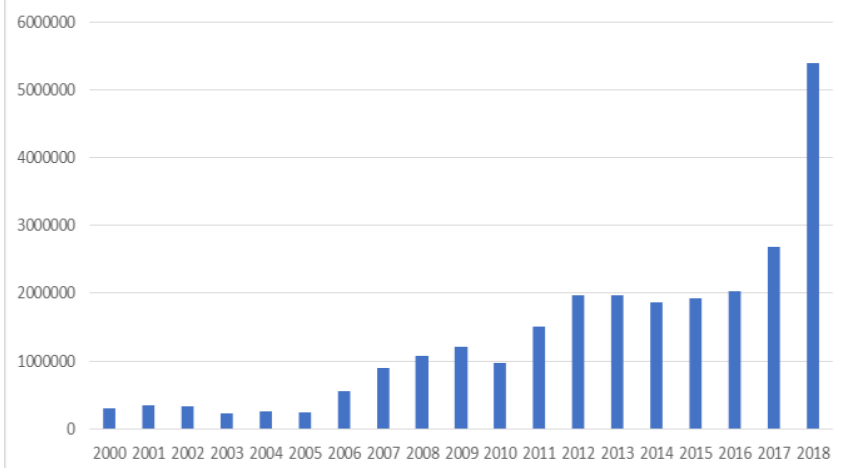

Source: State Committee data on tourism development in the Republic of Uzbekistan.

Fig.1 The dynamics of inbound tourism of Uzbekistan

The reason for this surprising rise in the number of tourists can be explained by eliminating visa regime for the citizens of 76 countries of the world. Now the citizens of many European countries, North and South America as well as Africa can enter Uzbekistan without any visa and stay for 30 days. The government is also trying to restructure the national air company "Uzbekiston Havo Yo'llari". This company dominates the domestic air travel. Some people argue that it is time to invite foreign air companies to Uzbekistan, so that price offerings went down ${ }^{3}$. According to Global Report on Aviation, "many governments have implemented open skies policies in order to remove protectionist and restrictive barriers between countries, reaching multilateral agreements in the European Union. The result has been a ten year increase in the number of air passengers and the openness of regional markets for air travel [3:68]. Likewise, it would be appropriate to open up air travel market for foreign air companies in Uzbekistan.

Neighboring Kazakhstan is one of the most visited places in Central Asia receiving 8.49 million people in $2018^{4}$. The openness of air travel market and other favorable conditions assisted to emerge low cost air companies such as FlyArystan, which generated surge in air travel in Kazakhstan $^{5}$. In order to ncrease the competitiveness of air transport network, the Uzbek government opened three airports (in Karshi, Nukus and Termez) for foreign air

\footnotetext{
${ }^{2}$ Uzbekistan Tourism Survey. June 2018. P.6

${ }^{3}$ https://kun.uz/69332997. Aziza Umarova. "95\% of the population will never see the sea cause of airline monopoly." July 9, 2019.

https://astanatimes.com/2019/02/inbound-tourism-to-kazakhstan-increas ed-10-percent-in-2018-over-previous-year/

https://astanatimes.com/2019/10/kazakh-airlines-carry-5-6-millionpassengers-in-first-eight-months-of-2019/
}

companies. Also, on the $19^{\text {th }}$ and $20^{\text {th }}$ February of 2020 year, it is planned to arrange the first international forum in Tashkent inviting international air companies across the world ${ }^{6}$. According to the survey carried out by State Committee of development for tourism (SCDT) in June 2018, most of the visitors to Uzbekistan (62.7\%) arrived via ground transportation from neighboring countries (Kazakhstan, Turkmenistan, Kyrgyzistan, Tadjikistan). The majority of tourists, who used air transport, used the services of “Uzbekiston Havo Yullari”(64.1\%), Air Astana (11.8\%), "Aeroflot"(5.7\%), Turkish Airlines (5\%) and UT Air $(4.2 \%)^{7}$.

Also, the survey revealed that only $16.8 \%$ of all sold tour packages in 2018 were realized by Uzbek tour operators and tour companies ${ }^{7}$. A great deal of buyers of Uzbek tour packages accounted for citizens of countries from Asia Pacific region (34.5\%) and Europe $(26.1 \%)^{7}$. The low proportion of tour package realization by local tour companies can be due to problems in management and marketing [9]. However, if we observe the websites of the biggest local tour companies such as Registon tour (http://registontravel.com/en) and Anur tour (https://www.tourstouzbekistan.com/), one can notice relatively higher prices for the tours than it is in developing countries such as Vietnam, Thailand or Turkey. Higher prices may distract groups of tourists such as students, who are very sensitive to price fluctuations. So in this regard, further work should be carried out to reduce the net cost of travel in Uzbekistan.

It is also important to take into account seasonality of tourism and analyze factors influencing the seasonal fluctuations. It is significant factor in shaping the competitiveness of touristic destinations [6]. We carried out econometric analysis, in order to evaluate the impact of one of the crucial factors- weather temperature on the number of tourist visits (fig.2).

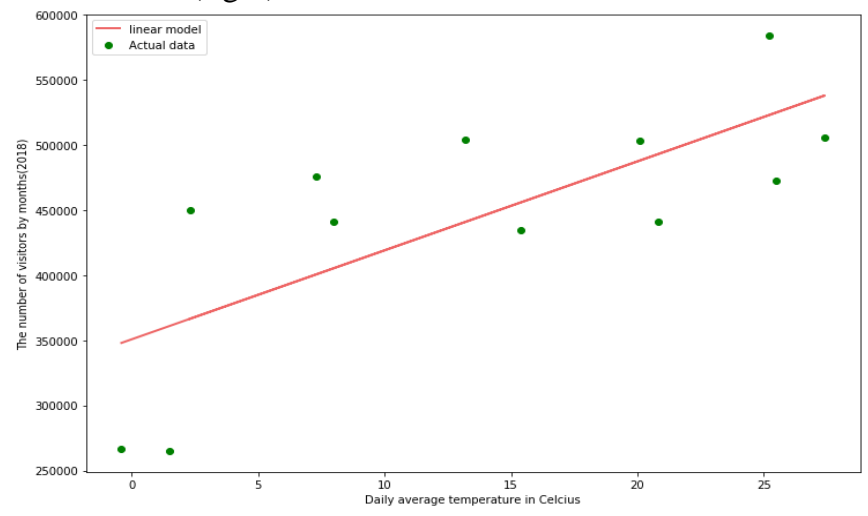

Source: The graph is produced by author.

Fig.2 The impact of weather temperature on the number of tourist visits for 2018

The fig. 2 is produced using the following statistical data:

6 https:/www.gazeta.uz/ru/2019/08/15/tourism-interview/ Aziz Abduhakimov. Decree on tourism can be called revolutionary. August 15 2019.

${ }^{7}$ Uzbekistan Tourism Survey June 2018. 
Table-I: Statistical data for 2018 year according SCDT

\begin{tabular}{|l|l|l|}
\hline Months & $\begin{array}{l}\text { Daily average } \\
\text { temperature in } \\
\text { Uzbekistan } \\
\text { (in Celsius) }\end{array}$ & $\begin{array}{l}\text { The number of } \\
\text { visitors by } \\
\text { months } \\
(2018)^{7}\end{array}$ \\
\hline January & $-0,4$ & 266194 \\
\hline February & 1,5 & 264936 \\
\hline March & 8 & 441134 \\
\hline April & 15,4 & 434962 \\
\hline May & 20,8 & 441500 \\
\hline June & 25,5 & 472907 \\
\hline July & 27,4 & 506105 \\
\hline August & 25,2 & 584434 \\
\hline September & 20,1 & 503305 \\
\hline October & 13,2 & 504390 \\
\hline November & 7,3 & 476131 \\
\hline December & 2,3 & 450221 \\
\hline
\end{tabular}

Based on official statistical data (SCDT, 2018), we constructed the following econometric model:

$\mathrm{Y}=350761.4+6837.53 \mathrm{X}$

Y-The number of visitors;

$\mathrm{X}$ - Daily average temperature in Uzbekistan in 2018.

The model can be interpreted as follows: one degree increase in temperature increases the number of visitors by 6837 people. Other important statistical data of this econometric analysis is given below:

Table-II: The outcome of the econometric analysis

\begin{tabular}{|l|l|l|}
\hline Variable & $\begin{array}{l}\text { Daily average } \\
\text { temperature }\end{array}$ & constant \\
\hline Coefficient & 6837.53 & 350761.4 \\
\hline Std. err. & 2013.17 & 33931.98 \\
\hline $\mathrm{t}$ & 3.4 & 10.34 \\
\hline $\mathrm{P}>|t|$ & 0.007 & 0.000 \\
\hline $\begin{array}{l}{[95 \% \text { conf. }} \\
\text { interval] }\end{array}$ & 2351.91 & 11323.16 \\
\hline R-square & 275156.2 & 426366.5 \\
\hline
\end{tabular}

The coefficient of determination (R-square) is 0.53 , which means the model explains $53 \%$ of change in the number of visitors. While the $p$ value is close to zero implying that variable is correctly chosen. The reason for low determination coefficient is due to the influence of other factors that haven't been included into the model such as marketing expenses, transportation costs and others. The seasonality affects badly the tourism industry, as it brings uncertainty for entrepreneurs and investors. In our view, having better and modern infrastructure can significantly reduce the negative effect of seasonal fluctuations.

With regard to the age of incoming tourists, the middle-aged people between 35 and 45 constituted the majority, of which the $29.4 \%$ were from Central Asia, $33.8 \%$ from CIS countries and 30\% from countries of Asia Pacific. $39.4 \%$ of all respondents' motivation of the visit was seeing their relatives and friends, while $33.6 \%$ responded that they came for leisure, vacation, and recreational purposes. ${ }^{9}$

8 https://ravelask.ru/questions/788864-pogoda-v-uzbekistane-po-mesya tsam. 2019

\footnotetext{
${ }^{9}$ Tourism in Uzbekistan survey 2018, P.5
}

All in all, it is clear that inbound tourism is rapidly developing in Uzbekistan. However, majority of guests are motivated to see their relatives, but not to use conventional touristic services. This may be due to relatively high prices of tour packages. The expensive air tickets issued by monopolist air company (O’zbekiston Havo Yo'llari) prevent price-sensitive groups of tourists from visiting Uzbekistan. In this case, the liberalization of air travel market is the only solution. Also, we found out that weather temperature significantly affects the number of visitation, and to eliminate the seasonality effect further development of infrastructure is necessary.

\section{DOMESTIC TOURISM ANALYSIS}

It is well known that domestic tourism is the main source of income for the tourism industry of any country.It accounted for $73 \%$ of total Travel \& Tourism spending in $2017^{10}$. We tried to analyze some trends in the domestic tourism across the regions of Uzbekistan. Interestingly, the most visiting population in Uzbekistan turned out to live in the Ferghana Valley (Andijan, Fergana and Namangan cities). As can be seen from the diagram below (fig.3), the regions with the lowest number of domestic tourists in the republic are Bukhara, Samarkand, Surkhandarya, Tashkent and Tashkent city. Actually, lower proportion of trips relative to the number population can imply that majority of people of the regions do not go on a trip within the country. The high intensity of local touristic trips is important because this provides the exchange of culture, knowledge, and funds from richer areas to poorer ones. Therefore, low number of trips from more developed regions such as Samarkand and Tashkent should be considered as signal to further encourage domestic tourism there.

\section{The number of local trips in regions.Diagram №2}

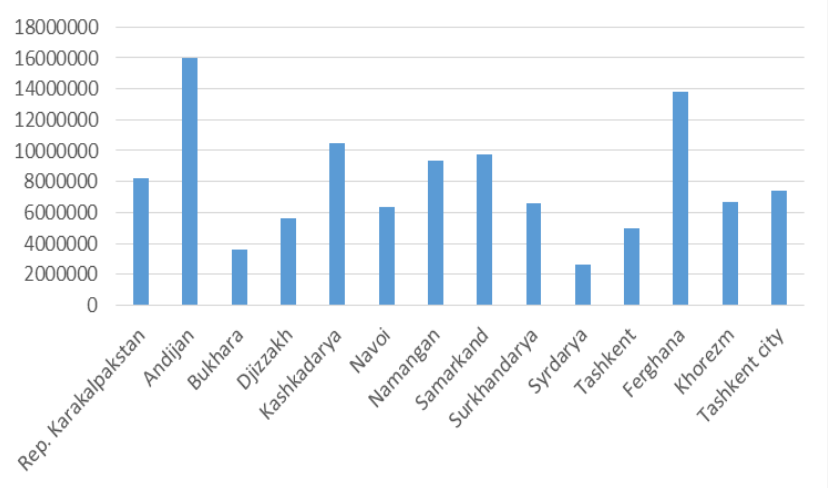

Source: State Committee data on development of tourism of Uzbekistan

Fig.3 The number of local trips in regions

Certainly, the increase in the number of visitation also depends on the capacity of transport and touristic infrastructure between and in regions.

Today, Uzbekistan is fully covered by railways and airports. The Spanish Bullet trains connect largest touristic cities such as Samarkand, Bukhara and Tashkent. However, surprisingly, there are still not many tour companies offering

\footnotetext{
${ }^{10}$ Domestic tourism. Importance and Economic Impact. World Travel \& Tourism Council. 2017 P.1
} 
cheap trips for students, who are highly mobile relative to other members of society. In our view, the price competitiveness of touristic services should be increased by reducing the net cost of travel within Uzbekistan.

When managing local travel agencies or hotels, the emphasis is being given on analyzing competitors and on short-term planning [8]. Problems with the collection and analysis of statistical data do not allow for long-term planning, forcing tourism managers to make intuitive decisions. It should be noted that the increase in the volume and quality of statistics in recent years has provided enterprises with new opportunities in the field of strategic planning. However, some statistics, for example, the distribution of tourist's spending by sources is not available on the websites of SCDT or department of statistics.

The experience of the developed countries such as USA, United Kingdom, Japan has shown that more detailed and open statistical information about tourists' arrival and other features will allow to develop effective planning and development strategies in tourism organizations. In particular, the development of various action scenarios and the development of a comparative analysis system for each scenario will help tourism company to optimize revenue as well as increase competitiveness. Here we tried to reflect domestic tourism demand in each region by using the indicator of tourist per room in a hotel. This indicator is calculated by dividing the number of received tourists to the number of rooms in hotels.

$$
\text { Tourist per room }=\frac{\text { Received tourists }}{\text { Thenumber of rooms }}
$$

If we look at the activities of hotels in 2018, we can see that the domestic demand for hotel services varied by region.

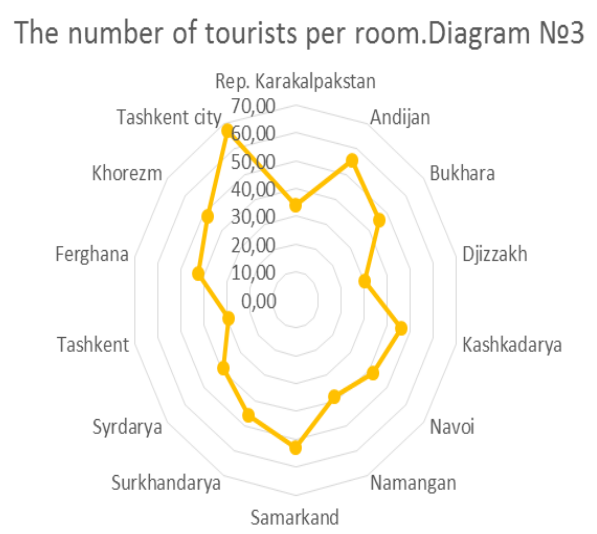

Source: The data of the State Committee of development for tourism of Uzbekistan for 2018

For example, hotels in Tashkent city hosted an average of 67 people per room, while in Tashkent region this figure equaled to only 29. Relatively higher rates were noted in Samarkand, Andijan, Surkhandarya, Kashkadarya, Bukhara and Khorezm regions. In the remaining areas, it accounted for less than 40 people per room. From these statistics, we can conclude that hotels in some regions are loaded much more than in others. Interestingly, all the areas with higher rates of tourist per room have relatively better infrastructure (roads, hospitals, railways, parks, historical sites and others).
Fig.4 The number of tourists per room

Therefore, it is sensible to encourage further development of general infrastructure in regions of Karakalpakstan, Djizzakh, Navoi, Sirdarya, and Tashkent. Ensuring continuous growth in tourism demand is largely dependent on high quality services [5]. High quality services usually create lasting impression on visitors, and this is particularly important for emerging destinations such as Uzbekistan. The classification of hotels can also assist to control quality in the process of service delivery. According to World Tourism Organization, the hotel rating system offer benefits to various sectors: travel agencies, tour operators, governments, and consumers [13]. Many hotel companies use classification as branding, which convey both qualitative and quantitative grading of properties to their customers [7]. The hotel rating system comprises two parts: basic registration standard, and grading standard [2]. The basic registration standard is the physical requirement that a hotel property must meet; it is the minimum quality requirement [7]. The grading standard is an extension of basic requirements of qualitative and intangible services, allowing a hotel to be compared with other properties. If we look at the situation on the share of rated hotels in Uzbekistan, we can see surprisingly large amount of non-classified types of accommodation (fig.5). According to the SCDT, out of 769 hotels registered in Uzbekistan in 2018, 452 do not have any categories.

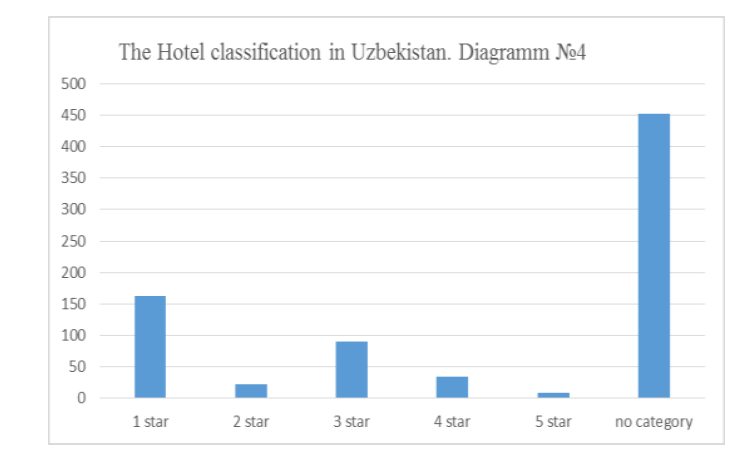

Source: The data of the State Committee of development for tourism of Uzbekistan for 2018

Fig.5 The Hotel classification in Uzbekistan

In general, classification can be used to assess the quality of services provided. If we look at the experience of developed countries, for example, in Spain since the 1980s, each hotel must have complaint books. This helps to look at hotels with a critical eye, and thereby achieve continuous improvement in quality. From a Spanish experience, it is justified that a similar approach can be applied to food and transport services, too [10] .Now, mobile phones allow people to leave their opinions on the corresponding website of the service, minimizing the subjective influence of the service provider on the assessment of the services provided. This means that the assessment is the most fair and that it is possible to objectively determine the opinion of the client for each type of service. Therefore, it is recommendable for all touristic services have their own websites, where it is possible to leave comments on delivered service. This not only increases awareness about quality, but also assists to adjust to the demand from customers in time, which is crucial in the business of tourism. 


\section{CONCLUSION}

We found out that the tourism industry in Uzbekistan largely depends on the objectivity and completeness of tourism statistics. This, in turn, opens up internal opportunities for tourism planning in the republic, organizing high-quality services and increasing the competitiveness of tourism. The seasonal fluctuations in inbound tourism turned out to be highly dependent on weather temperature, as it is in many other destinations. Also, it became clear that only small proportion of tour packages were realized by local tour companies and tour operators, which is not encouraging. Regarding the domestic tourism, the population of most developed regions did not travel much to other less developed regions, probably because of poor infrastructure and lack of information. Therefore, it is necessary that government and private tourism companies carry out marketing activities and contribute to the development of infrastructure in less developed regions.

Besides, the high share of non-classified hotels threaten to increase uncertainty in tourism market, especially for tour operators, which try to sell tour products to the more sophisticated customers. Therefore, in our view, it is advisable to review the registration and grading standards so that more accommodation types could be rated. All in all, in this article we were able to identify general trends and drawbacks in the tourism sphere of Uzbekistan using statistical information and statistical analysis. This once again justifies the power of statistics in evaluating complex processes.

\section{REFERENCES}

1. Bartle D. (2015).The Use of Statistics to Evaluate Tourism Policy. UNWTO. P.1

2. Callan, R. J. (1993). An appraisal of UK hotel quality grading schemes.. International Journal of Contemporary Hospitality Management, 5(5): 10-18.

3. Global Report on Aviation. UNWTO (2012), P.68

4. Holloway J.C, Humphreys C., Davidson R. (2009). The Business of Tourism. $8^{\text {th }}$ edition Pearson Education Limited. P.121

5. Kandampully J., (2000). The impact of demand fluctuations on the quality of service: a tourism industry example. Managing Service Quality: International Journal.

6. Lee Ch, Bergin-Seers S., Galloway G., Mahony B.O., McMurray A. (2008). Seasonality in the tourism industry Impacts and Strategies. Sustainable Tourism. P.11

7. Naragavana Y, Hu Bo, (2008). The Relationship between the Hotel Rating System, Service Quality Improvement, and Hotel Performance Changes: A Canonical Analysis of Hotels in Thailand. Journal of Quality Assurance in Hospitality \& Tourism.

8. Safarov B. (2010) Problems of Planning in Touristic Companies. Samarkand State University Journal. P. 301-306.

9. Safarov B. (2017) Ways of Increasing Efficiency of Touristic Companies. Journal of innovative technologies. Tashkent State University of Economics P.31-39

10. Solsten E. and Meditz S.(1988) Spain: A Country Study. Washington: GPO for the Library of Congress

11. Trochim, W. (1998), ‘An Evaluation of Michael Sriven's “Minimalist Theory: The Least Theory that Practice Requires", American Journal of Evaluation, volume 19 (2), pp.2453-249, Sage, Los Angeles.

12. Twining-Ward, L. (2009), Sub-Saharan Africa Tourism Industry Research. Final report for World Bank, Washington DC. http://goo.gl/tV9Z9W

13. UNWTO (2014). Tourism market trends. In Facts \& figures: Information, analysis, and know-how http://www.world-tourism.org/facts/tmt.htm

\section{AUTHORS PROFILE}

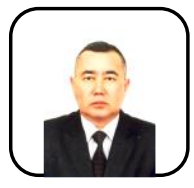

Prof. Mirzaev Kulmamat Janzakovich was born in 1961. He did bachelor degree in agricultural economics in Tashkent Institute of National Economy. In 1982 he started to work as a junior researcher at the All-Union Karakul Research Institute of Samarkand. In 1989 he completed his postgraduate studies at the All-Union Agricultural Research Institute in Moscow and were employed in the All-Union Karakul Research Institute of Samarkand, and later in Agricultural Economics and Management of the Samarkand Agricultural Institute. In 1996 he started to work as associate professor in the Samarkand Agricultural Institute. In 1998 he was promoted to the head of the department of Agricultural Economics and Management of the Samarkand Agricultural Institute. Between 2004 and 2005 he practiced in Training and Retraining Centre of Samarkand Agricultural Institute. After that he worked in the Treasury department of the Samarkand region and in Samarkand Institute of Economics and Service. Since 2015 he is working as a vice-rector on educational issues in the institute.

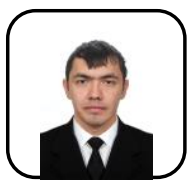

Janzakov Bekzot Kulmamat ugli was born in 1991. In 2015 he graduated his bachelor degree and in 2017 he completed his masters in economics in Samarkand Institute of Economics and Service. From August 2017 till October 2018 he practiced as an accountant in the Samarkand branch of JSC JV Uz British American Tobacco, and currently taking his postgraduate studies in Samarkand State University. He published a paper 'The Role of Investments in the Development of Uzbek Economy, Russia' in the journal called 'Economy and entrepreneurship' (Экономика и Предпринимательство) Edition 12, Part 2, December 2016.

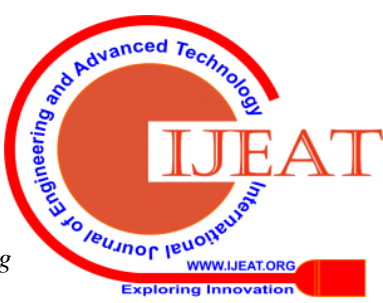

